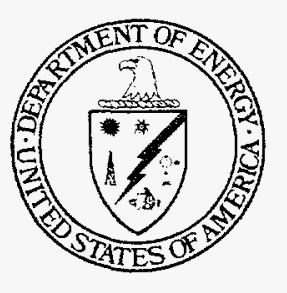

LWRHU EB WELD DEVELOPMENT

L. A. Greene

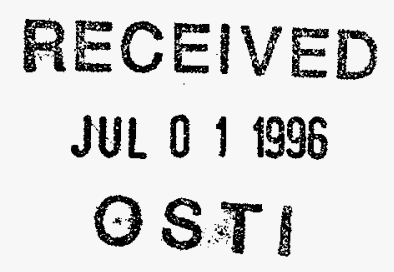

January 22, 1980

FOR REERENCE

DOT TO BE TAKEN

7ant mon $500 \mathrm{n}$

\title{
MOUND FACILITY
}

Miamisburg, Ohio 45342

operated by

MONSANTO RESEARCH CORPORATION

a subsidiary of Monsanto Company

for the

U. S. DEPARTMENT OF ENERGY

Contract No, DE ACQ4-76-DPDODS3 


\section{DISCLAIMER}

Portions of this document may be illegible in electronic image products. Images are produced from the best available original document. 


\section{LWRHU EB WELD DEVELOPMENT.}

\section{A. Greene}

\section{INTRODUCTION}

Electron beam weld development studies were performed for both the platinum frit vent-to-vent cap weld and also the vent cap-to-body weld for the LWRHU Project using a Hamilton Standard EBW-6 Electron Beam Welder.

A total of six (6) development welds each was performed to establish welding parameters and procedures which would produce satisfactory and acceptable welds.

The relatively small size of the platinum frit vent dictated that the fritto-vent cap weld would have to be limited as to depth of penetration and also to minimize the reduction of the porous frit areas.

\section{POST-WELD INSPECTION}

\section{A. Frit Vent-to-Vent Cap Weld}

Visual and metallographic inspections showed all welds to be acceptable. Two welds showed a very slight tilting of the frit vent during welding due to a slightly loose fit-up, but this was not considered objectionable.

No serious problem with porosity was evident with any of the welds inspected. The flow rates on two of the welded frit vents were checked to determine if the welding operation in any way had altered the flow rates of the frit vents. The result of this flow rate check before and after welding showed no significant change.

Photomicrographs of a $180^{\circ}$ transverse section and the as-welded condition of a typical frit vent-to-vent cap EB weld are shown in Figures 1 and 2. 


\section{B. Vent Cap-to-Body Weld}

The EB weld development studies on the vent cap-to-body weld were performed on six (6) capsules. (Twenty other vent cap-to-body welds were initially made, but these welds were not subjected to metallographic inspection until after the GTA closure weld development had been performed. Upon reviewing the photomicrographs of several of these welds, prel iminary data were obtained.) Final EB weld development studies were then performed on six (6) other capsules.

Due to some tilting of the vent cap to body during welding, it was decided that the vent cap should be held in place during the welding of the vent cap to the body. To accomplish this, a small tack welding fixture was constructed, whereby each vent cap would be tack welded to the body prior to performing the vent cap-to-body weld. The tacking fixture can accommodate up to eight (8) capsules. Each vent cap is tack welded to the body in two (2) places $180^{\circ}$ apart using this tack welding fixture.

Because some weld undercutting (which is typical with this type of weld) was noted, a cosmetic weld pass was incorporated immediately after the initial vent cap-to-body weld.

Photomicropraphs of a $180^{\circ}$ transverse section and the as-welded condition of a typical capsule are included in figures 3 and 4 .

\section{SUMMARY}

Acceptable EB welds were made on both the frit-vent-to-vent cap welds and the vent cap-to-body welds.

Weld porosity was not a problem with either weld.

A list of the various EB welding parameters is also included with this report and are provided in Table 1. 


\title{
TABLE 1
}

\section{EB WELD PARAMETERS}

\section{Frit Vent to Vent Cap}

\author{
$30 \mathrm{KV}$ \\ $1.0 \mathrm{MA}$ \\ $0.010^{\prime \prime}$ Deflection \\ Speed Setting - Variable Start 180 \\ Focus Setting - 280
}

Tack Weld Vent Cap to Body

$60 \mathrm{KV}$

$2.0 \mathrm{MA}$

$0.010^{\prime \prime}$ Deflection

Tack Weld Two (2) Places $180^{\circ}$ Apart

Beam On and Off Manually

Vent Cap to Body Weld

\author{
90-95 KV \\ 2.0 MA \\ $0.005^{\prime \prime}$ to $0.010^{\prime \prime}$ Deflection \\ Speed Setting 55-60 = 4 to $5 \mathrm{Sec} / \mathrm{Rev}$. \\ Focus Setting - 450 \\ Total Weld Time 8 to $10 \mathrm{Sec}$.
}

\section{Cosmetic Weld}

$60 \mathrm{KV}$

2.0 MA

Speed Setting - 40

$0.010^{\prime \prime}$ to $0.015^{\prime \prime}$ Deflection

Focus Setting - 350 to 360

\section{DISCLAIMER}

This report was prepared as an account of work sponsored by an agency of the United States Government. Neither the United States Government nor any agency thereof, nor any of their employees, makes any warranty, express or implied, or assumes any legal liability or responsibility for the accuracy, completeness, or usefulness of any information, apparatus, product, or process disclosed, or represents that its use would not infringe privately owned rights. Reference herein to any specific commercial product, process, or service by trade name, trademark, manufacturer, or otherwise does not necessarily constitute or imply its endorsement, recommendation, or favoring by the United States Government or any agency thereof. The views and opinions of authors expressed herein do not necessarily state or reflect those of the United States Government or any agency thereof. 


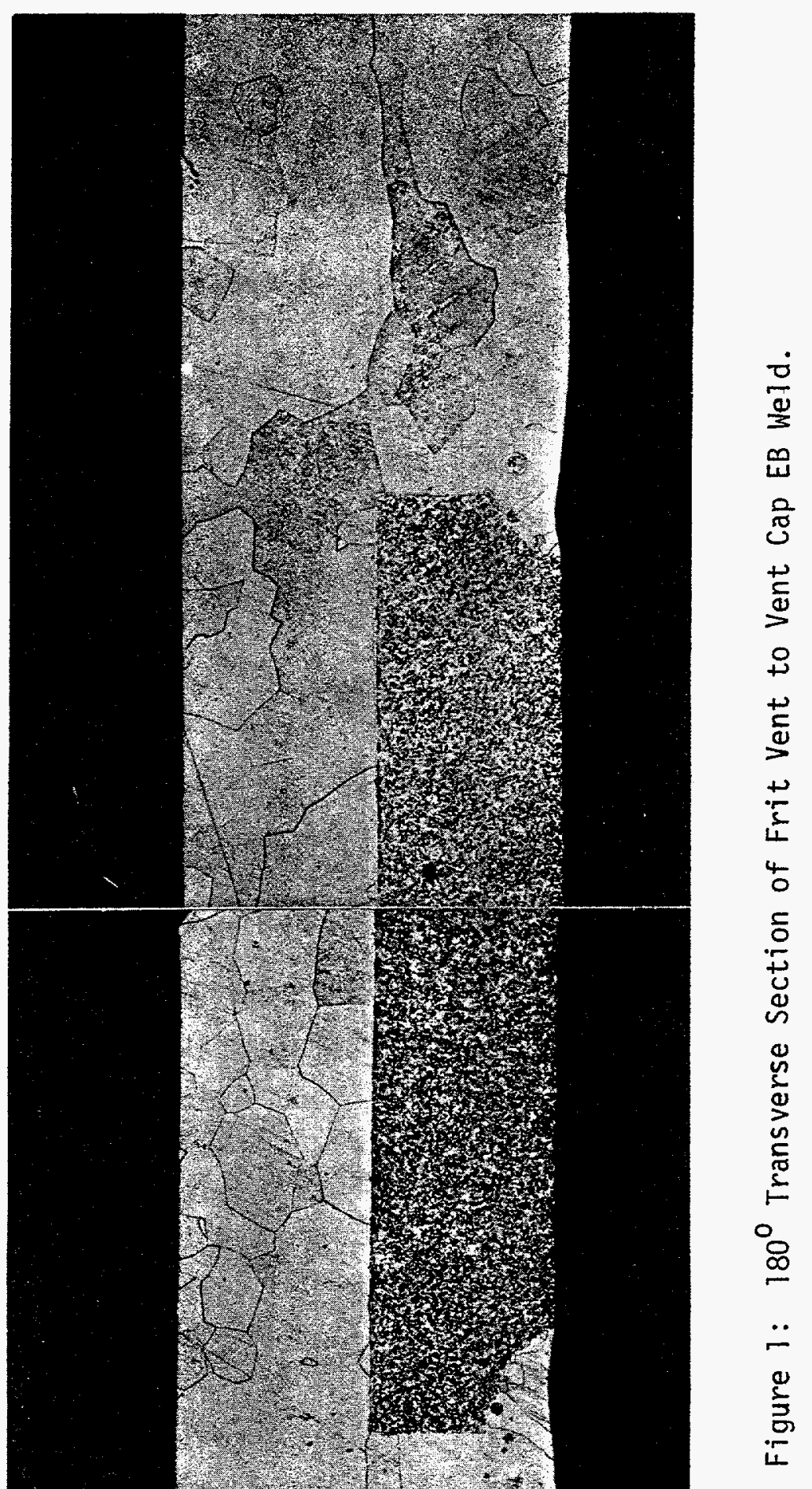




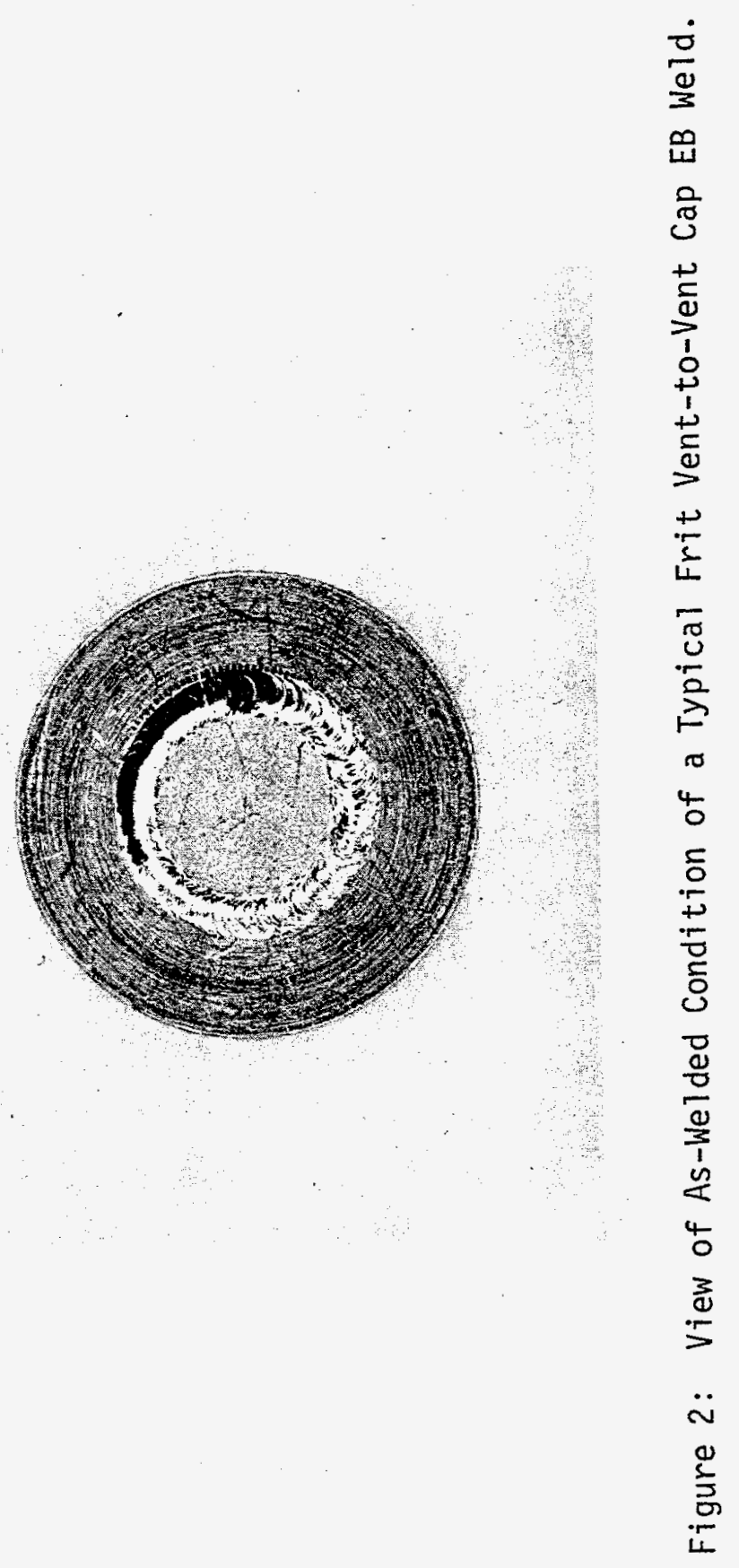




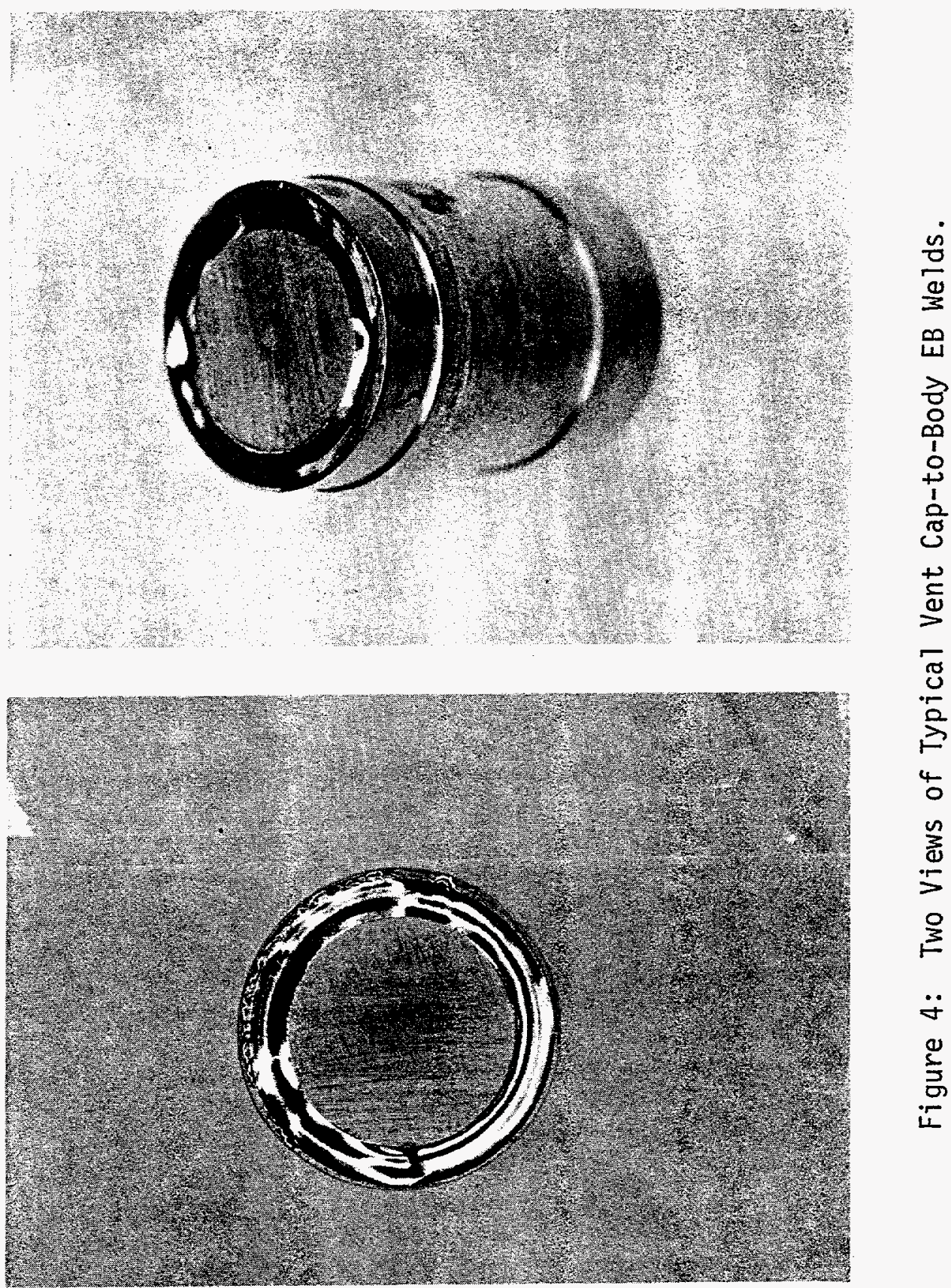

